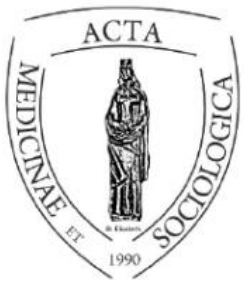

Acta Medicinae et Sociologica (2021)

Vol. 12. No. 32. (133-140)

UNIVERSITY OF

DEBRECEN

doi:

FACULTY OF

HEALTH

https://doi.org/10.19055/ams.2021.05/31/7

NYÍREGYHÁZA

\title{
Kovács Eszter Karolina: „Egészség és tanulás a köznevelési típusú sportiskolákban” címü könyvéről
}

Bagaméri Bernadett ${ }^{1}$

${ }^{1}$ MA hallgató, Debreceni Egyetem Bölcsészettudományi Kar Nevelés- és Művelődéstudományi Intézet, Neveléstudomány MA, 4032 Debrecen, Egyetem tér 1.

bagameribernadett@yahoo.com

Kovács Eszter Karolina „Egészség és tanulás a köznevelési típusú sportiskolákban" című könyve az egészségmagatartás, az egészségtudatosság és a tanulmányi eredményesség összefüggését vizsgálja. A kérdést egy speciális csoportra koncentrálva elemzi, amikor a sportiskolák diákjait választja célcsoportjának, akiket az eredményességi szempontok mentén összehasonlít a hagyományos középiskolák diákjaival. A kutatás vizsgálja az egészségmagatartási és a tanulmányi eredményességre gyakorolt intézményi hatást, az egészségmagatartás faktorok (egészségtudatosság, megküzdés, szorongás) és a tanulmányi teljesítmény kapcsolatát, illetve ennek a kapcsolatnak az erősségét.

Az olvasó érdeklődését első pillantásra felkelti a könyv borítója. Lila háttéralapon egy színtelen, egyszerü, vázlatos képet jelenít meg, amely viszont találó módon ábrázolja a sportolás és a tanulás együttesét öt, különböző testhelyzetben lévő emberalak formájában. A háttérben három emberalak álló helyzetben, sporteszközöket tartva cselekvésre készen jelenik meg, míg az előtérben ülő két figura laptopról, illetve könyvből olvas. Az ábra dinamizmust, lendületet sugároz, szinte érezni lehet az alakok motiváltságát, elszántságát úgy a sportolás, mint a tanulás területén.

A téma aktualitását és jelentőségét előtérbe helyezi, hogy magyarországi és európai viszonylatban magas az inaktivitás és az egészségkárosító magatartásformák aránya a népesség körében. Az egészségtudatosság és az egészséges életmódra törekvés hiánya megmutatkozik a fiatalkorúak és iskoláskorúak és a felnőttek körében is. A Nemzeti Alaptanterv éppen ezért kiemelt hangsúlyt fektet a testnevelésre, megcélozza az egészség, a 
mozgáskultúra és a személyiség fejlesztését. Mindemellett a jelen kutatásban vizsgált jelenségek (tanulmányi és nem tanulmányi eredményesség) kutatására a köznevelési típusú sportiskolák tanulóinak körében korábban még nem került sor.

A recenzált könyvben bemutatott kutatás a szerző doktori disszertációja alapján készült, amelyet a Debreceni Egyetem Humán Tudományok Doktori Iskola keretén belül védett meg. A könyv szerzője végzettségére nézve iskolapszichológia szakirányon végzett pszichológus és szakfordító, a Felsőoktatási Kutató és Fejlesztő Központ (CHERD) tagja, a Debreceni Egyetem Nevelés- és Művelődéstudományi Intézetének tanársegéde, emellett pedig a Hungarian Educational Research Journal (HERJ) föszerkesztőhelyetteseként, valamint a Book reviews és Research rovatok szerkesztőjeként is dolgozik. Fő kutatási területét a serdülők egészségmagatartása és egészségtudatossággal kapcsolatos attitüdjei képezik, amelyeket neveléstudományi és pszichológiai szempontok mentén vizsgál. Eddigi munkássága során az említett témaköröket föként a köznevelési típusú sportiskolákba járó diákok körében kutatta, de vizsgálódott emellett a felsőoktatás terén is. A könyv az Oktatáskutatók Könyvtára sorozatban jelent meg.

A szerző az egészségtudatosság, illetve az ebből adódó egészségmagatartás kérdéskörét, és ennek tanulmányi eredményességgel való összefüggéseit járja körül a könyvben, középiskolai tanulók, tehát főként serdülökorú fiatalok körében. Egészségmagatartás alatt érthetünk minden olyan cselekvést, illetve attitüdöt, amely kihatással van az egyén egészségi állapotára, akár pozitív, akár negatív irányban befolyásolja azt. Az egészségmagatartás fogalma tehát magában foglalja - a szerző értelmezésében - az egészséget védő, protektív és preventív jellegű viselkedésminták mellett mindazokat a magatartásformákat is, amelyek káros, sőt romboló hatással vannak az egyén egészségére nézve. Ide tartozik például a nem megfelelő táplálkozás, a fizikai mozgás mennyiségének elégtelensége vagy hiánya, a túl korán kezdett szexuális élet, valamint az olyan rizikófaktorok, mint a dohányzás, a rendszeres alkoholfogyasztás és a kábítószer használat, amelyek mind komoly problémát jelentenek napjainkban, nem csupán a felnőttek, hanem a fiatalkorúak körében is. A szerző elsősorban az utóbbi három tényezőt vizsgálja, mint az egészségtudatosság és egészségmagatartás mutatóit. Fő célcsoportként a köznevelési típusú sportiskolák diákjait méri fel, és hasonlítja össze hagyományos középiskolában tanuló fiatalokkal. 
A vizsgálat kiemelkedő újszerüségét bizonyítja, hogy a sportiskolák felmérése ezen a téren mindezidáig váratott magára, holott az intézmény egyik fontos, vállalt küldetése az utánpótlás nevelés mellett az egészségtudatosságra nevelés. Azt azonban, hogy ezt a célt mennyire sikerül megvalósítaniuk a gyakorlatban, és mennyire sikerül növelni a sportiskolások körében az egészségtudatosság mértékét, előzetes kutatások nem ellenőrizték. A kutatás tehát az egészségmagatartást, mint nem tanulmányi eredményességet elemzi, és veti össze a tanulmányi eredményességgel (az év végi osztályzatok, szubjektív tanulmányi teljesítmény, és az Országos Kompetenciamérés eredményei alapján), a sportiskolások és nem sportiskolások körében. Ezáltal a sportiskolák hozzáadott értékét is igyekszik feltárni -ez a kutatási kérdés szintén előzmény nélküli -, valamint fontosnak tartja összehasonlítani öket ebben tekintetben is a hagyományos középiskolákkal.

A könyv egy rövid előszó után, a bevezetésben felhívja a figyelmet az egészségtudatosság és az erre való nevelés fontosságára, valamint hangsúlyozza a kutatás aktualitását. Az ezt követő három fejezet a kutatás elméleti hátterét, az előzetes kutatási eredményeket és a témában releváns szakirodalmi tényeket vázolja fel és összegzi. Az ötödik fejezetben a szerző néhány korábbi, a jelenlegi kutatás alapjául szolgáló kutatását, illetve annak eredményeit mutatja be, valamint részletezi a könyv kérdésfelvetéseit, céljait, hipotéziseit, a felmérésben alkalmazott eszközöket, s a vizsgált populáció sajátosságait. A további fejezetek a kutatás eredményeinek részletes bemutatásával és tárgyalásával foglalkoznak, a tizedik fejezet pedig ezek összegzését és a kutatás korlátait tartalmazza. A fejezetek frappáns, figyelemfelkeltő címeket viselnek, egy-egy rövid és lényegre törő kérdés formájában megfogalmazva (,Egészségesebbek-e a sportiskolások?” vagy „Jobb tanulók-e a sportiskolások?”), ami arra késztet, hogy megkeressük a fejezetben felkínálkozó válaszokat. Az összegzés után következő függelék részben megtaláljuk a kutatás kérdőíveit, a beleegyezési nyilatkozatokat, és bizonyos táblázatokat. Ezt követi a tanulmány magyar és angol nyelvü kivonata, a táblázatok és ábrák jegyzéke, végső soron pedig a felhasznált szakirodalmakat felsorakoztató bőséges hivatkozásjegyzék. A harminc oldalon át sorolt szakirodalom, arról tanúskodik, hogy a kötet létrejöttéhez számos hazai és nemzetközi forrásmunka szolgáltat széleskörü, gazdag tudományos, szakmai alapot. A szerző stílusára a tudományos igényesség, pontosság és részletesség jellemző, amely kiterjed úgy az elméleti megalapozásra, mint a kutatás módszertanára és eredményeinek bemutatására is. 
Most lássuk a kötet legfontosabb megállapításait! A sportiskoláról lényegét tekintve elmondható, hogy egy olyan köznevelési intézmény, amely legfontosabb feladatának a verseny- illetve élsportolói utánpótlás - nevelést tekinti, és ezt a nevelést akkreditált sportági tantervek alapján végzi. A sportiskolákat bemutató fejezetben a szerző kitér ezen intézmények nemzetközi viszonylatban történő bemutatására, amelyben kifejti azok kulcsfontosságú közös vonásait és három alapvető típusát, a teljesen integrált, a részlegesen integrált, valamint a magániskolaként müködő típusokat. Hazai viszonylatban, a témában fontos a kettős kategorizálás, azaz az egyesületi jellegü -, és a köznevelési típusú sportiskola, amelyek részletesebb bemutatására is sor kerül. Ugyanebben a fejezetben röviden kitér a könyv a sportiskolások társadalmi hátterére is - amelyet majd a későbbiekben részletez -, hangsúlyozva a család és a szülők részéről érkező támogatás fontosságát, amelynek a sportiskolai tanulók esetében nemcsak a személyiségfejlődésre és a tanulásra, hanem a sportkarrier megvalósíthatóságára is ki kell terjednie. A könyv következő, A soktényezös egészségtudatosság címü fejezete az egészségmagatartás témakörét definiálja és járja körül, különös figyelmet fordítva a serdülő korosztály sajátosságaira. Erre az identitáskereső időszakra jellemző, hogy az egészségromboló magatartásformák megnövekedett mértékben fordulnak elő, amelynek hátterében számos tényező állhat (pl. felnőttes viselkedés imitálása, csoportnorma követése stb.). Az egészség tekintetében levonható a következtetés, hogy mindhárom egészségromboló viselkedés nemzetközi viszonylatban is magas arányban fordul elö a hazai iskoláskorú fiatalok körében, ami komoly veszélyeztetést jelent a diákok egészségére nézve. Az egészségkárosító magatartásformák kerülése mellett az egészségtudatosság másik kulcsfontosságú tényezője a sport és az edzettségi állapot, amelynek nem megfelelő volta szintén komoly egészségügyi kockázati tényező, mivel a mozgás számos pozitív fiziológiai és pszichológiai, egészségvédő hatással rendelkezik. A szerző ugyanakkor arra is felhívja a figyelmet, hogy egyes kutatások pozitív kapcsolatot találtak a sportolás és a rizikómagatartások között, elsősorban a verseny- és élsportolók körében, amely magyarázható a versennyel járó állandó stresszhelyzet és teljesítménykényszer átélésével, valamint a teljesítmény növelésének vágyával. A továbbiakban a kötet a serdülőkorra koncentrálva kitér az egészségkárosító magatartással összefüggő és azt befolyásoló számos tényező vizsgálatára, intra- és interperszonális, valamint környezeti szinten egyaránt. Az ezt következő fejezetet a szerző az egészségtudatosság és a tanulmányi eredményesség összefüggéseinek korábbi kutatási eredmények tükrében 
történő elemzésére szenteli. Az egészségtudatosság témakörén belül a sport, a rizikómagatartás és a mentális egészség tanulmányi eredményességgel való kapcsolatát mutatja be. A sportolás számos, a szervezetre kifejtett pozitív hatásán keresztül képes javítani a tanulmányi eredményességet, ugyanakkor a sportolói lét fontos aspektusa az is, hogy a mindennapos edzés, a versenyekre való felkészülés nagyon sok időt és energiabefektetést igényel a sportoló diák részéről, amely ezáltal háttérbe szoríthatja a tanulást.

A jelenlegi kutatás elővizsgálataiban a szerző kidolgozott egy új, hiánypótló kérdőívet, amely az egészségtudatosságot és az egészségmagatartást komplex rendszerként, annak minden vonatkozásával együtt képes felmérni. A mérőeszköz az Egészséggel Kapcsolatos Attitüdök Kérdőív elnevezést kapta. A szerző korábban már vizsgálta a tanulmányi eredményesség, az egészségmagatartás és a lemorzsolódás összefüggéseit a sportiskolások és nem sportiskolások diákokat összehasonlítva. A jelenlegi kutatás résztvevői serdülő diákok voltak, összesen 3015 tanuló, akik három-három köznevelési típusú sportiskolából, illetve három-három hagyományos középiskolából kerültek kiválasztásra Magyarország hét különböző régiójából. A résztvevők szelekciója többlépcsős rétegzett mintavétel által valósult meg, amely biztosítja a kutatás reprezentativitását. A kutatás fontos célkitüzései közé tartozik a sportiskolák tanulói összetételének és jellemzőinek vizsgálata, a tanulmányi és nem tanulmányi (egészségmagatartás) eredményesség feltárása, amelyeket összehasonlít a nem sportiskolai tanulók jellemzőivel és eredményeivel. A kutatás kérdésfelvetései abból a szempontból is nagyon lényegesek, hogy a sportiskolák vizsgálata a kérdéses szempontok mentén mindezidáig váratott magára. A kutatás négy alapvető hipotézisből indul ki, amelyek a családi háttérre, az egészségtudatosság és egészségmagatartás, valamint a tanulmányi eredményesség különbségeire, illetve ezek viszonyára fókuszálnak. A vizsgálatban felhasznált eszközök egy szocio-demográfiai kérdőív-, általános egészségmagatartási kérdőív, az előzetes kutatásban kifejlesztett egészségtudatossággal kapcsolatos attitüdök kérdőív, szorongást, megküzdést, jóllétet, spirituális jóllétet, illetve tanulmányi eredményességet mérö, önkitöltős kérdőívek voltak.

A szerző a logikusan felállított és egymásra épített előfeltevések mentén haladva prezentálja kutatásának eredményeit, amelyeket minden esetben ábrákkal, illetve táblázatokkal szemléltet. A kutatási eredmények tekintetében a szerző áttekintő leírást ad a résztvevők demográfiai jellemzőiről, majd részletesen taglalja a családi-, társadalmi háttér sajátosságait, amelyeket régiónként is felvázol. A kutatás első hipotézise azt feltételezi, hogy a 
sportiskolák tanulói alacsonyabb társadalmi hátterüek, mint a nem sportiskolás diákok. A területi különbségeket számba veszi az egészségtudatosság mutatói mentén is, elemzi a szubjektíven megítélt egészségi és edzettségi állapotot, az egészségtudatossági indexet, amelybe belesorolja a táplálkozást, a fizikai aktivitást, a dohányzást, az alkohol- és drogfogyasztást, az agressziót, a telefon- és internethasználatot, a szubjektív egészségi állapotot, valamint az érzelmi egyensúlyt. Feltárja továbbá a szorongás és a megküzdés különbözö típusai mentén, valamint a jóllét és spirituális jóllét vonatkozásában jelentkező releváns területi eltéréseket. Ezeket a különbségeket régiókra bontott, szemléletes térképekkel ábrázolja. A második hipotézis szerint ugyanis a sportiskolások nem tanulmányi (egészségmagatartási) eredményessége magasabb a hagyományos középiskolákban tanulókéhoz viszonyítva. A szöveges összehasonlítást minden szempont mentén diagramok és táblázatok kísérik, amelyek egyrészt strukturálttá és átláthatóvá teszik azt, másrészt pedig szemléletesen kiemelik a két csoport jellemzőiben mutatkozó eltéréseket, illetve hasonlóságokat. A nem tanulmányi eredményesség tekintetében a dohányzási, az alkoholfogyasztási és a szerhasználati szokások mellett, olyan aspektusokat is szemügyre vesz, mint a folyadék-, kávé-, gyorséttermi ételekés energiaital fogyasztás, az alkoholfogyasztással járó szórakozás, az alvásmennyiség, valamint a területi különbségek esetében is felvázolt pszichológiai tényezők, amelyek mentén érdekes és több esetben nem várt eltérések mutatkoznak a két vizsgált csoport között. Az egészségtudatosság és egészségmagatartás tekintetében nem egyértelmüen kijelenthető, hogy egyik vagy másik csoport az eredményesebb, hiszen a különböző vizsgált kritériumok mentén eltérő eredményességgel jellemezhetőek. A sportiskolás diákok körében nagyobb arányban fordul elő a kábítószer kipróbálása, gyakoribb az alkoholfogyasztás, ugyanakkor több vizet fogyasztanak és nagyobb alvásmennyiség jellemző rájuk, míg a hagyományos iskolákban tanuló fiatalok gyakrabban fogyasztanak gyorséttermi ételeket és bort. Összességében elmondható az eredmények alapján, hogy a sportiskolások az egészségtudatosság, a megküzdés, jóllét, spirituális jóllét és a szubjektív edzettségi állapot tekintetében eredményesebbek társaiknál. Mentálisan tehát tudatában vannak a rizikóviselkedések veszélyeinek, ami azonban nem minden esetben valósul meg a mindennapi gyakorlat során. A szerző figyelme kiterjed az intézményi hozzáadott érték vizsgálatára is a két típusú intézmény vonatkozásában. Ez esetben azt feltételezi, hogy a sportiskolák jelentős hozzáadott értékkel bírnak az egészségtudatosság és egészségmagatartás tekintetében, ez azonban csak a spirituális jóllét terén figyelhető meg, negatív 
irányban. Eredményeinek ezen vonatkozását is a részletekre kiterjedő alapossággal, diagramokkal szemléltetve mutatja be. A kötet harmadik hipotézise azt feltételezi, hogy a sportiskolás diákok tanulmányaikban is eredményesebbek a nem sportiskolás társaiknál. A tanulmányi eredményességet többféle szempont mentén mérte és elemzi a szerző. Vizsgálta az egyéni megítélés, a tanárok és szülők szerinti szubjektív vélemény, a nyelvvizsga megléte, a versenyeken való részvétel, a 2016-os Országos Kompetenciamérés eredményei alapján, ez utóbbit részletes területi, régiók szerinti bontásban is bemutatja. Az eredmények ebben a tekintetben szinte minden vizsgált mutató mentén ellentmondanak a feltételezéseknek. Az egészségtudatosság és tanulmányi eredményesség közötti kapcsolatot tíz különböző tantárgy teljesítménye alapján elemzi és prezentálja a szerző, ezt követően pedig az egészségtudatosságra és a tanulmányi eredményességre ható tényezők terén feltárt eredmények kerülnek bemutatásra. Ezen tényezők között jelen van a nem, a sportiskolai tagság, a versenysport, a szülők iskolai végzettsége, a szubjektív és objektív anyagi helyzet, valamint a településtípus hatásának vizsgálata. A negyedik összetett hipotézis azt várja, hogy az egészségtudatosság magasabb foka jobb tanulmányi teljesítménnyel jár együtt, amelyet a szerző Pearson-féle korreláció segítségével ellenőrzött, az eredmények pedig beigazolják a várakozásokat. Továbbá feltételezi a szerző, hogy a nők egészségtudatosabbak, hogy a sportiskola és a versenysportolás, a szubjektív egészségi és edzettségi állapot, a vallásosság, a megküzdési rugalmasság, a jóllét és spirituális jóllét pozitívan, míg a szülők magasabb iskolai végzettsége, a jobb anyagi helyzet, a nagyobb településtípus és a magas szorongás negatívan befolyásolja az egészségtudatosságot. A hipotézis ellenőrzésére lineáris regresszió-analízist és kétmintás t-próbát használt a szerző. A hipotézis ezen részét részben erősítik meg az eredmények. Végül a szerző által felállított egészségmagatartási klaszterek (deviáns, flegma, kiegyensúlyozott, stresszes) megoszlását szemlélteti a tanulmány a nem, az évfolyam, a szülők iskolai végzettsége, a lakóhely típusa, a szubjektív vallásosság, illetve a régiók szerint. A klaszterekbe tartozók jellemzőit itt részletesen is kibontja a könyv. A vizsgálat során nyert adatokat és eredményeket minden esetben táblázatokkal, grafikonokkal, a területi megoszlások adatait pedig térképábrákkal támasztja alá és prezentálja a kötet.

A kötetről összességében elmondható, hogy fontos hiánypótló munka, amely a kutatói figyelmen méltatlanul kívül rekedt köznevelési típusú sportiskolák müködésével foglalkozik, elsősorban az ott tanuló diákok jellemzőire, összetételének sajátosságaira, az egészségtudatosság és 
egészségmagatartás, valamint a tanulmányi teljesítmény és eredményesség vizsgálatára összpontosítva. A könyv a sportiskolákat nem önmagában, hanem a hagyományos középiskolai rendszerrel való alapos és igényes összehasonlításban taglalja és mutatja be, amely lehetővé teszi a két különböző típusú intézmény egymáshoz viszonyított előnyeinek, erősségeinek, illetve gyengeségeinek tudatosítását, alapot adva ezáltal az esetlegesen fejlesztésre érdemes aspektusokon való elgondolkodásra. A könyvet ajánlom azoknak az intézményvezetőknek, gyakorló szakembereknek, pedagógusoknak, pszichológusoknak, akik sportoló fiatalokkal foglalkoznak, és pályájukat, fejlődésüket, életútjukat igazgatják, mert a kötet lehetőséget ad e diákok hátterének, jellemzőinek, problémáinak jobb megismerésére, megértésére. A kutatás fókuszpontjában lévő intézmények vezetőinek, illetve az intézményben dolgozó szakembereknek érdemes kifejezett figyelmet fordítaniuk a könyvre, amely rávilágítva az esetleges gyengeségekre, alapot adhat az intézmény hatékonyságának, eredményességének növeléséhez. Ajánlom továbbá minden oktatáskutatónak, a sportolás pszichológiai vetületeit vizsgáló kutatónak, pszichológusnak, illetve hasznos lehet a munka azoknak a szülőknek és diákoknak, akik iskolaválasztás elött állva komolyan gondolkodnak a sportiskolán, mint lehetséges opción, valamint minden, a sportolói lét, a sportolás egészségtudatossággal és tanulmányokkal összefüggő hatásai iránt érdeklődőnek.

Kovács Eszter Karolina (2020): Egészség és tanulás a köznevelési típusú sportiskolákban. Debrecen, Debreceni Egyetem Felsőoktatási kutató és Fejlesztő Központ CHERD 